\title{
Methodical Approaches to the Assessment of Innovative Region Susceptibility
}

\author{
Olga Nikolaevna Vladimirova
}

\author{
Doctor of Economics, professor \\ olgav@akadem.ru \\ Aida Talyatovna Petrova
}

Doctor of Economics, professor, Siberian Federal University, Russia, 660041,

Krasnoyarsk, Svobodnij Prospect, 79

petrovaaida@rambler.ru

\section{Doi:10.5901/mjss.2015.v6n3p11}

\section{Abstract}

In modern conditions, questions assessing the effectiveness of innovative development of regions are among the most urgent. The generalization of global and domestic experience in implementing innovations indicates a discussion of issues in this area. The paper aims to study the indicators for assessing innovation. The authors of the study on the basis of terminological apparatus of innovation management clarify the concept of "innovation susceptibility of the region," define the relationship with the existing interpretation of the categories and conceptual apparatus. Consideration of the theoretical aspects of innovation susceptibility necessitates the development of its quantitative and qualitative parameters of evaluation. Authors proposed a methodological approach to the evaluation of innovative susceptibility region tested in the territories belonging to the Siberian Federal District. Comparison with the system of indicators used in the international practice and the practice of the countries in the CIS, confirms the correlation proposed indicators with indicators measuring innovation. At the same time, the use of the values of individual parameters for the integrated assessment of the susceptibility of the region's innovation is a fairly complex task associated with the introduction of a heterogeneous database performance. The paper proposes a comprehensive model for integrating disparate figures, the weight value of each factor and to identify priorities for the development of the region to achieve the target value. Empirical IP-repetition made on the basis of the static data and the processing results of initial authors of qualitative parameters for 2001-2009 years, as the absence of a source of statistical information for the last 4 years, limited to the time period of the study. This technique allows not only formalizing and defining the level of development of complex socio-economic systems at the micro and macro levels, to identify the potential for growth, but also based on the specified management of different levels of development prospects, identify priority areas of growth.

Keywords: innovation susceptibility, assessment indicators, innovation potential, innovative climate, target values, factor model

\section{Introduction}

The processes taking place in the global economy cause priority of innovative development. In the global economy twopoled business-economic system is formed. At one pole (USA and EU) there is the production of money, brands and know-how, on the other (China and other developing countries) - the production of goods. In the open market after Russia's WTO accession competitiveness is of major importance, which can be achieved at the expense of innovational development (Borodin , 2013).

Fundamentals of the theory of innovation development set out in the writings of I. Schumpeter (Schumpeter, 1982), B. Lundvall (Lundvall, 1992), R. Nelson (Nelson,1993), K. Freeman(Freeman, 1995). The generalization of existing international and domestic experience of innovation implemention states quite clearly there is a number of discussions in this area. These questions include assessing the effectiveness of innovative processes.

The appeal to the results of Russian studies showed the presence of a variety of methodological approaches of the definition of indicators used for such purposes. In particular, focus on the innovative potential is done in the works of E.A. Utkin, G.S. Gamidova, S. Mityakov, O. Mityakova (Hamidov, 2000; Mityakov,2005). The innovative climate is seen in the writings of the Ural scientists A.I .Tatarkina, I.M.Golovi, A.F. Suhovey (Tatarkin, Sukhovey, 2005). The innovative activity is described by V.N. Kiselev, R.A. Fatkhutdinov (Head,2004; Fatkhutdinov, 2007). The innovation competitiveness questions are described by V.V. Ovchinnikov, T.G. Filosofova and V.N. Bykov. In world practice known publication by M. Muchie, A. Baskaran (Muchie, Baskaran, 2013), P. Intarakumnerd, J.Vang (Intarakumnerd, Vang, Lundvall, 2006), K.J. 
Joseph, C. Chaminade (Joseph, Chaminade, Vang, Lundvall,2010).

At the same time, often used the term "innovative susceptibility" is not defined in any one source. The authors propose to consider innovative susceptibility of the region as presence and the ability of regional subjects and bodies of the executive power to create, execute and implement innovative processes based on existing conditions and resources within a particular and ongoing national and regional innovation policy (Vladimirova, 2011).

\section{The Main Part}

The concept of "innovation susceptibility" has a logical connection to the other categories of the conceptual apparatus of innovation management, such as the innovation potential, innovation climate, innovative activity, innovation competitiveness. The study proposed in the scientific literature, reference books, legal acts of innovative interpretations of a number of terminology suggests that rates of innovation have a certain relationship. It is clear that innovative susceptibility should create conditions for innovation, to which it is necessary to relate the availability of innovative capacity and consequently form the basis for the formation of innovative climate, implementation of innovative activity and innovation competitiveness. The innovative potential and innovative climate record the availability of resources, innovative activity and competitiveness - the impact of innovation. The innovative susceptibility represents the summation of resource component, the readiness of subjects to develop, implement and realize the innovation, and the effect of the interaction of these elements in the form of outcome indicators (Figure 1).

\section{Results}

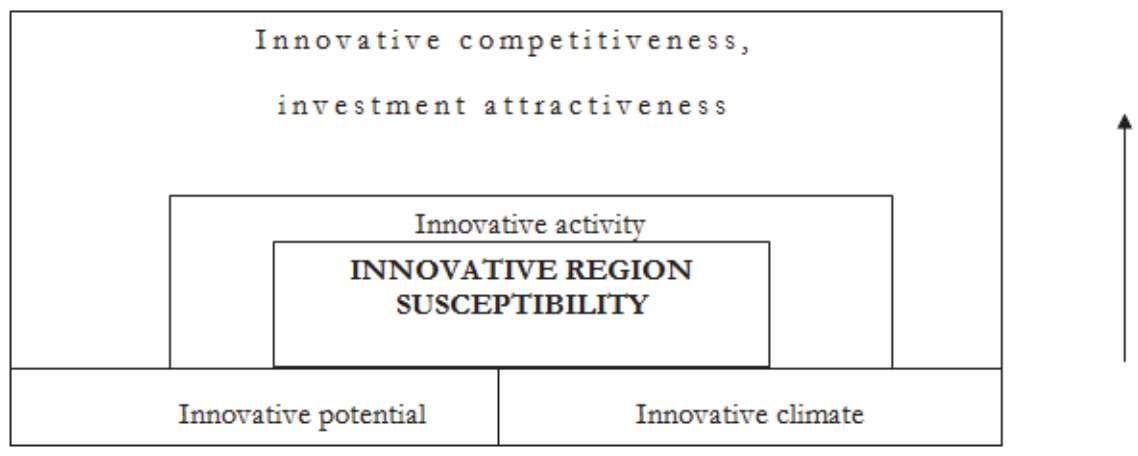

Fig. 1 - The relationship of the concept "innovation receptivity" to the categories of the theory of innovation management

Thus, this model is a complex multi-level system, forming an innovative competitiveness and investment attractiveness of the region. At the same time, innovation receptivity, being a sub-system that is focused on the building a rational strategy for the implementation of inno-ODL paradigm in relation to a particular region. Consequently, innovation competitiveness and management of innovation susceptibility should be related as the purpose and means.

The consideration of the theoretical aspects of innovation receptivity explains the need to develop its quantitative and qualitative evaluation criteria. The method of calculating the integral indicator of innovation receptivity, based on a set of private indicators (Table 1), the approach to the construction of an innovative rating susceptibility described in detail in (Vladimirova, 2011). For the purpose of testing the methodology, empirical studies have been conducted in the regions that are a part of the Siberian Federal District (SFD) (Vladimirova,2011).

The innovative susceptibility of the region is formed under the cumulative interaction of the two systems of factors reflecting, on the one hand, innovative climate in the region, and on the other - its innovative potential. The conducted terminological analysis suggests that the definition of "innovation climate" is a set of conditions that reflects the social, nature-geographic, communication, technological, scientific, technical, economic, financial, political and legal sphere of the region and in the synthesis can be represented as using indicators "regional standard field" and "infrastructure support" (Table 1).

In its turn, to the system of indicators that reflects the innovative potential of the region can be attributed indicators: the proportion of the population engaged in research and development; the share of innovation active organizations; the proportion of acquired research and development funds in their total cost; the share of domestic expenditure on research and development in the GRP (GDP); the share of expenditure on technological innovation in the GRP (WFP); the share of innovative products, services and works in GRP (WFP) and the proportion of the economically active population. 
Table 1 - The system of private indicators to measure innovation receptivity of the region

\begin{tabular}{|c|c|c|}
\hline Index & \multirow{3}{*}{$\begin{array}{l}\text { Calculation method } \\
\text { population of } \mathrm{R} \& D \\
\text { the total number of the employed population } \\
\text { number of innovation active enterprises } \\
\text { the total number of registered enterprises }\end{array}$} & $\begin{array}{l}\text { Information base (State Statistics } \\
\text { section of the report) }\end{array}$ \\
\hline The share of employment in $R$ \&D & & $\begin{array}{l}\text { Research and innovation; } \\
\text { Employment and labor }\end{array}$ \\
\hline Share of innovation active organizations & & $\begin{array}{l}\text { Research and innovation; } \\
\text { Companies and Organizations }\end{array}$ \\
\hline $\begin{array}{l}\text { The share of acquired research and } \\
\text { development funds in their total value }\end{array}$ & $\begin{array}{c}\text { value of acquired research and development funds } \\
\text { the total value of fixed assets }\end{array}$ & $\begin{array}{l}\text { Research and innovation; National } \\
\text { wealth }\end{array}$ \\
\hline $\begin{array}{l}\text { The share of domestic expenditure on } \\
\text { research and development in the GRP } \\
\text { expenditure on technological innovation }\end{array}$ & $\begin{array}{l}\text { domestic expenditure on research and development } \\
\text { GDP(WFP) }\end{array}$ & Scientists investigated and \\
\hline $\begin{array}{l}\text { The share of expenditure on technological } \\
\text { innovation in the GRP (WFP) }\end{array}$ & \begin{tabular}{|c|} 
expenditure on technological innovation \\
GDP(WFP) \\
\end{tabular} & Gross Regional product; National \\
\hline $\begin{array}{l}\text { The share of expenditure on technological } \\
\text { innovation in the GRP (WFP) }\end{array}$ & \begin{tabular}{|c|} 
volume of innovative products, services and works \\
GDP(WFP)
\end{tabular} & \\
\hline $\begin{array}{l}\text { Proportion of the economically active } \\
\text { population }\end{array}$ & $\begin{array}{c}\text { the number of economically active population } \\
\text { the total number of the population }\end{array}$ & Employment and labor \\
\hline Regional standard field & a number of regional regulations on innovation & $\begin{array}{l}\text { Internet sites data "Science and } \\
\text { innovation in the region" and the }\end{array}$ \\
\hline Infrastructure provision & $\begin{array}{l}\text { the number of available infrastructure institutions } \\
\text { the number of institutions of leading regions }\end{array}$ & $\begin{array}{l}\text { Federal Portal Science and } \\
\text { Innovation activities }\end{array}$ \\
\hline
\end{tabular}

At the same time the question of correlation appears about the proposed indicators in measuring innovation used in world practice. For the evaluation and comparative analysis of innovation of countries and regions it is widely used the technique of the experts of the World Economic Forum to assess the competitiveness, a technique of the Commission of European Communities (CEC), the method of the Organization of Economic Cooperation and Development (OECD), the methodology of the American Science Foundation (NCF) (11Innovation Measurement, 2014). In international practice, it is also widely known the techniques that form the so-called "Frascati Family". The synthes and comparison of indicators is given in Table 2.

The calculation of indicators for the assessment of innovative region susceptibility on the above term, using traditional methods of univariate analysis is not difficult. Using the values of the individual parameters for the integrated assessment of the susceptibility of innovation in the region is a rather difficult task associated with the introduction of a heterogeneous data. The standard approach to the formation of summative evaluation of any economic phenomenon in the presence of heterogeneous quantitative terms is usually limited to the use of well-known economic and statistical methods of calculating the arithmetic unit, geometric unit by relative index of the process or the method of sums without the inclusion or inclusion into the system of the weight values, etc. The effectiveness of the model, describing the state of a complex socio-economic phenomenon, largely caused not only by the choice of quantitative and qualitative indicators, but also a mathematical algorithm allowing to generate a functional dependency. In addition, the model should fit in a technique that enables the management to solve the problem with the definition of a place in the region at the federal level and to identify potential opportunities to move the territorial education at any level of the outsider status into the leading one. Thus, there is a need to develop an integrated model that will take into account the diverse indicators, the weight value of each factor and to identify priorities for the development of the region to achieve the target value.

In our view, to solve the problem you should use the proposed by N.V. Shalanov (Shalanov,2005) and successfully tested by the author technique (Petrova,2006) which is based on the theory of potentials J. Huht and P. Meyer(Hunt ,1962; Meyer,1973) . 
Table 2 - Indicators to assess the innovativeness

\begin{tabular}{|c|c|c|}
\hline $\begin{array}{l}\text { The system of indicators of innovative } \\
\text { development of the Republic of Belarus } \\
\text { (The State Program ...,2011) }\end{array}$ & $\begin{array}{l}\text { Innovative susceptibility } \\
\text { (Vladimirova,2011) }\end{array}$ & $\begin{array}{l}\text { Indicators of the European innovation scoreboard (2010) (European } \\
\text { Innovation Scoreboard, 2010) }\end{array}$ \\
\hline $\begin{array}{l}1 \text { The number of employees involved in } \\
\text { research and development }\end{array}$ & $\begin{array}{ll}2 & \text { The share of employment in } \\
\text { research and development }\end{array}$ & $\begin{array}{l}\text { Conditions for Innovation (Innovation Drivers) } \\
\text { 1.1 Staff who have received a degree or higher education per } 1000 \\
\text { population aged 20-29 } 1.2 \text { Population with tertiary education per } 100 \\
\text { population aged 25-64 } \\
1.3 \text { The level of broadband (the number of broadband connections per } \\
100 \text { inhabitants) 1.4 Participation in continuing education per } 100 \\
\text { population aged 25-64 } \\
1.5 \text { The level of education of young people (\% of population aged 20-24 } \\
\text { with completed secondary education) }\end{array}$ \\
\hline $\begin{array}{l}1 \text { The share of innovation - active } \\
\text { organizations in the total number of } \\
\text { industrial enterprises }\end{array}$ & $\begin{array}{l}3 \text { The share of innovation - active } \\
\text { organizations }\end{array}$ & $\begin{array}{l}3 \text { Innovation and Entrepreneurship (Innovation \&Entrepreneurship) } \\
\text { 3.1 Small and medium-sized enterprises (SMEs), developing their own } \\
\text { innovations (\% of SMEs) }\end{array}$ \\
\hline \begin{tabular}{|l}
2 Share of costs for equipment, tools \\
and accessories for investment in \\
fixed capital
\end{tabular} & \begin{tabular}{|l}
4 Share of acquired research and \\
development funds in their total \\
value
\end{tabular} & There is no analogue \\
\hline $\begin{array}{l}3 \text { Gross domestic expenditure on } \\
\text { research and development in GDP }\end{array}$ & $\begin{array}{|ll|}5 & \begin{array}{l}\text { The share of domestic expenditure } \\
\text { on research and development in } \\
\text { the GRP (GDP) }\end{array} \\
\end{array}$ & $\begin{array}{l}\text { 2 An investment in knowledge (Knowledge Creation) } \\
\text { 2.4 Share of enterprises receiving public funding for innovation }\end{array}$ \\
\hline $\begin{array}{l}4 \text { Indices domestic expenditure on } \\
\text { research and development }\end{array}$ & \begin{tabular}{|ll}
6 & Share of expenditure on \\
& technological innovation in the \\
& GRP (WFP)
\end{tabular} & $\begin{array}{l}\text { 2 An investment in knowledge (Knowledge Creation) } \\
\text { 2.2 Expenditure on business research and development activities (\% of } \\
\text { GDP) } \\
\text { 2.3 The share of research and development costs of technologies }\end{array}$ \\
\hline 5 There is no analogue & $\begin{array}{|ll|}7 & \text { The share of economically active } \\
\text { population }\end{array}$ & $\begin{array}{l}4 \text { Applications (Applications) } \\
4.1 \text { Employment in high-tech business (\% of total labor force) } \\
4.5 \text { Employment in the manufacturing technology of medium and high } \\
\text { level (\% of total labor force) }\end{array}$ \\
\hline $\begin{array}{l}6 \text { Share of new products in total } \\
\text { industrial output; }\end{array}$ & $\begin{array}{|ll|}8 & \text { The share of innovative products, } \\
& \text { services and works in GRP (WFP) }\end{array}$ & $\begin{array}{l}\text { 4 Applications (Applications) } \\
\text { 4.2 Share of high-tech exports in total exports } \\
\text { 4.3 Sales of new exporting firms in foreign markets (\% of total turnover) } \\
\text { 4.4 Sales of new products firms (\% of total turnover) }\end{array}$ \\
\hline $\begin{array}{l}7 \text { The share of certified products in the } \\
\text { total volume of industrial productivity }\end{array}$ & 9 there is no analogue & $\begin{array}{l}\text { Intellectual Property (Intellectual Property) } \\
\text { 5.1 EPO patents per million population } \\
\text { 5.2 USPTO patents per million population } \\
\text { 5.3 Triad patents per million population } \\
\text { 5.4 The new trademarks per million population } \\
\text { 5.5. New design elements per million population }\end{array}$ \\
\hline $\begin{array}{l}8 \text { Creating and certification of quality } \\
\text { management systems according to } \\
\text { ISO }\end{array}$ & 10 Infrastructure provision & $\begin{array}{l}3 \text { Innovation and Entrepreneurship } \\
3.2 \text { Innovative SMEs to cooperate with others (\% of SMEs) } \\
\text { 3.5 The cost of information and communication technologies (\% of GDP) } \\
\text { 3.6 SMEs using Innovation (\% of MSP) }\end{array}$ \\
\hline $\begin{array}{|ll|}9 & \text { The deterioration of the active } \\
\text { industrial fixed assets at end of year }\end{array}$ & 11 There is no analogue & There is no analogue \\
\hline $\begin{array}{l}\text { 10 The share of innovative products in } \\
\text { the total volume of production in the } \\
\text { total volume of industrial output }\end{array}$ & $\begin{array}{l}12 \text { The share of innovative products, } \\
\text { services and works in GRP (WFP) }\end{array}$ & $\begin{array}{l}\text { 4 Application (Applications) } \\
\text { 4.2 Share of high-tech exports in total exports } \\
\text { 4.3 Sales of new exporting firms in foreign markets (\% of total turnover) } \\
\text { 4.4 Sales of new products firms (\% of total turnover) }\end{array}$ \\
\hline $\begin{array}{l}\text { 11The increase in financial expenses for } \\
\text { research and development at the } \\
\text { expense of the national budget }\end{array}$ & 13 There is no analogue & $\begin{array}{l}\text { 3 Innovation and Entrepreneurship (Innovation \&Entrepreneurship) } \\
\text { 3.3 Expenditure on innovation (\% of total turnover) } \\
\text { 3.4. Venture capital in the initial stage (\% of GDP) } 2 \text { An investment in } \\
\text { knowledge (Knowledge Creation) 2.1. Public expenditure on research and } \\
\text { development activities (\% of GDP) }\end{array}$ \\
\hline 12There is no analogue & 14 Regional standard field & There is no analogue \\
\hline
\end{tabular}

Compiled by the authors according to (The State Program...,2011; Vladimirova,2011; European Innovation Scoreboard, 2010)

This technique allows not only to formalize and define the level of development of complex social and economic systems at the micro and macro levels, to reveal the potential for growth, but also, based on the set of different management level development of prospects, to identify priority areas of growth.

Summing of initial parameters in a complex hierarchical system using the theory of potentials produced by calculating the ratio between the result obtained by the formed functional dependence and the maximum possible or 
desired value for the system.

The objective of this phase of the study is to describe two blocks of terms of the first level (Figure 1) and mixing them into a comprehensive assessment on the second level of the system.

On the basis of the static data and the results of processing by the authors the original quality parameters for the years 2001-2009 (Vladimirova,2011), it was decided to divide the dynamical rank into two periods 2001-2006 and 20062009, due to fracture-governmental stages of economic development of the country. Unfortunately, the lack of some statistical information for the last 4 years, limited time period of the study.

The comparative analysis of the Russian Federation and regions of the Siberian Federal District, found that in the Tomsk region the highest level of innovation receptivity is achieved. Therefore, as the target (threshold) values for the two time intervals 2001-2005 and 2006-2009, parameters of this RF subject are established. The value of the indicator "proportion of the economically active population" in the Krasnoyarsk region is higher than in Tomsk Region. As in the case like this as a reference you can use the maximum actual index achieved in a given period of time or remove this option from the model as reached the peak meaning.

In the tables №3 and №4 weighting parameters in the complex model on the block I «innovative potential of the region" were calculated and on the block II «innovation climate" for the two periods was calculated. For visual presentation of the results, the relative values in the block I are designed in ppm. The numbering of figures in the block is given in the order of their position and indicated by the symbol «l», a period of time is determined by the last digit of the year (1-5, 6-9) and marked «j», belonging to the unit - «k».

The calculation algorithm proposed standardization of each indicator (gr. 8-12 Table. 3 and gr.7-10 Table. 4) and the corresponding target values (Table 3 gr.13 and gr. 11 Table 4) using the standard deviation (gr.7 Table. 3 and gr. 5 Table. 4), calculated by the dynamic rank. Standardized values are indicated by the symbol "*". Further, the weighting values of diverse indicators in the block are defined according to the formula:

$$
\beta_{j k}=\frac{Z_{j k}^{*}}{\sqrt{\sum_{j=1}^{n}\left(Z_{j k}^{*}\right)^{2}}}
$$

A functional model is formed for each block and in general can be represented as follows:

$Y_{k}=\sum_{j=1}^{n} \beta_{k j} * x_{k j}^{*}$

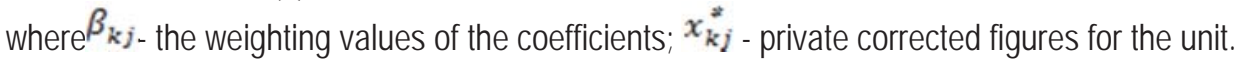

Table 3 - Calculation of parameters of a functional model based on data for the period 2001-2005

\begin{tabular}{|c|c|c|c|c|c|c|c|c|c|c|c|c|c|c|c|c|c|c|c|}
\hline \multirow{3}{*}{ Units } & \multirow{3}{*}{ Indexes } & \multirow{3}{*}{ 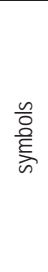 } & \multicolumn{5}{|c|}{$\begin{array}{l}\text { Evidence in the context of data } \\
\text { blocks }\left(x_{k i j}\right)\end{array}$} & \multirow{2}{*}{ 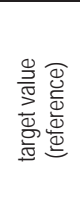 } & \multirow[b]{2}{*}{ 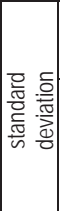 } & \multicolumn{5}{|c|}{$\begin{array}{c}\text { Standardized value evidence } \\
\text { years, }\left(z_{k i j}\right)\end{array}$} & \multirow{2}{*}{ 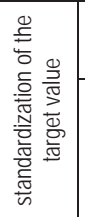 } & \multicolumn{2}{|c|}{ on 7-featured } & \multicolumn{2}{|c|}{ on 6-featured } \\
\hline & & & \multirow[t]{2}{*}{ ¿্ণ } & \multirow[t]{2}{*}{ ర్రి } & \multirow[t]{2}{*}{ ర్రి } & \multirow[t]{2}{*}{ চ্ণ } & \multirow[t]{2}{*}{ ஜํㅇ } & & & \multirow[t]{2}{*}{ ठ্ণ } & \multirow[t]{2}{*}{ ণ্ণ } & \multirow[t]{2}{*}{ ஜ্ঠి } & \multirow[t]{2}{*}{ ర્ટે } & \multirow[t]{2}{*}{ ஜ્ટે } & & 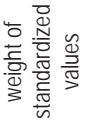 & \multirow[t]{2}{*}{ rank } & 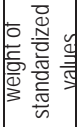 & \multirow[t]{2}{*}{ rank } \\
\hline & & & & & & & & $\left(x_{k j}^{*}\right)$ & $\left(\sigma_{\mathrm{ki}}\right)$ & & & & & & $\left(z_{k j}^{*}\right)$ & $\left(\gamma_{k j}\right)$ & & $\left(\beta_{k j}\right)$ & \\
\hline A & 5 & $B$ & 1 & 2 & 3 & 4 & 5 & 6 & 7 & 8 & 9 & 10 & 11 & 1 & 13 & 14 & 15 & 16 & 17 \\
\hline \multirow{7}{*}{ 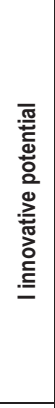 } & $\begin{array}{l}\text { share of population employed in research } \\
\text { and development, \%o }\end{array}$ & $\mathrm{x}_{11}$ & 5,4 & 5,20 & 5,10 & 4,90 & 4,90 & 17,2 & 0,04 & 150,0 & 144,4 & 141,7 & 136,1 & 136,1 & 477,8 & 0,609 & 2 & 0,998 & 1 \\
\hline & \begin{tabular}{|l|} 
share of innovation - active \\
organizations, $\%$
\end{tabular} & $x_{12}$ & 2,8 & 4,30 & 5,30 & 5,70 & 6,70 & 14,5 & 1,76 & 1,59 & 2,45 & 3,01 & 3,24 & 3,81 & 8,25 & 0,011 & 5 & 0,017 & 4 \\
\hline & $\begin{array}{l}\text { the proportion of acquired research and } \\
\text { development funds in their total cost, \%o }\end{array}$ & $x_{13}$ & 5,4 & 4,00 & 9,00 & 3,50 & 5,20 & 36,0 & 3,71 & 1,45 & 1,08 & 2,42 & 0,94 & 1,40 & 9,69 & 0,012 & 4 & 0,020 & 3 \\
\hline & $\begin{array}{l}\text { the share of domestic expenditure on } \\
\text { research and development in the GRP,\% }\end{array}$ & $\mathrm{x}_{14}$ & 5,6 & 6,9 & 7,9 & 6,6 & 6,3 & 13,4 & 0,57 & 9,82 & 12,10 & 13,85 & 11,57 & 11,04 & 23,49 & 0,030 & 3 & 0,049 & 2 \\
\hline & $\begin{array}{l}\text { the share of expenditure on technological } \\
\text { innovation in the GRP (WFP),\%o }\end{array}$ & $X_{15}$ & 2,1 & 1,00 & 3,00 & 5,50 & 3,20 & 7,8 & 2,22 & 0,95 & 0,45 & 1,35 & 2,48 & 1,44 & 3,52 & 0,005 & 6 & 0,007 & 5 \\
\hline & $\begin{array}{l}\text { the share of innovative products, services } \\
\text { and works in GRP (WFP),\%o }\end{array}$ & $X_{16}$ & 3,0 & 2,6 & 8,1 & 7,7 & 10,3 & 25,2 & 9,15 & 0,33 & 0,28 & 0,88 & 0,84 & 1,13 & 2,75 & 0,004 & 7 & 0,006 & 6 \\
\hline & $\begin{array}{l}\text { proportion of the economically active } \\
\text { population, \% }\end{array}$ & $x_{17}$ & 5,1 & 5,20 & 5,25 & 5,29 & 5,38 & 5,4 & 0,01 & 588,6 & 600,2 & 605,9 & 610,6 & 620,9 & 620,9 & 0,792 & 1 & $x$ & $X$ \\
\hline \multirow{2}{*}{ 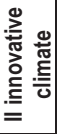 } & regional standard field & $x_{21}$ & 1,6 & 1,6 & 1,6 & 1,6 & 1,6 & 1,0 & 0,00 & $x$ & $x$ & $x$ & $X$ & $X$ & $X$ & $X$ & $X$ & $X$ & $X$ \\
\hline & infrastructure provision & $x_{22}$ & 4,0 & 4,0 & 4,0 & 4,0 & 4,0 & 5,0 & 0,00 & $X$ & $x$ & $x$ & $x$ & $x$ & $x$ & $x$ & $x$ & $x$ & $x$ \\
\hline
\end{tabular}


Table 4 - Calculation of parameters of a functional model based on the data for the years 2006-2009

\begin{tabular}{|c|c|c|c|c|c|c|c|c|c|c|c|c|c|c|c|c|c|}
\hline \multirow{3}{*}{ Units } & \multirow{3}{*}{ Indexes } & \multirow{3}{*}{$\begin{array}{l}\frac{0}{0} \\
\text { 点 }\end{array}$} & \multicolumn{4}{|c|}{$\begin{array}{c}\text { evidence in the context of } \\
\text { blocks years, }\left(x_{k i j}\right)\end{array}$} & \multirow{2}{*}{ 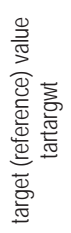 } & \multirow{2}{*}{ 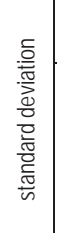 } & \multicolumn{4}{|c|}{$\begin{array}{c}\text { standardized value } \\
\text { evidence years, }\left(z_{k i j}\right)\end{array}$} & \multirow{2}{*}{ 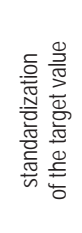 } & \multicolumn{2}{|c|}{ on 7-featured } & \multicolumn{2}{|c|}{ on 6-featured } \\
\hline & & & 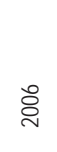 & চ̊̀ & 怘 & \&্ণ & & & ๕̊ & ڤ్రి & 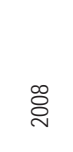 & 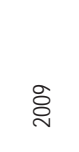 & & 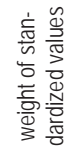 & rank & 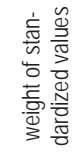 & rank \\
\hline & & & & & & & $\left(x_{k j}^{*}\right)$ & $\left(\sigma_{\mathrm{k}}\right)$ & & & & & $\left(z_{k j}^{*}\right)$ & $\left(\gamma_{k j}\right)$ & & $\left(\beta_{k j}\right)$ & \\
\hline $\mathrm{A}$ & 5 & $B$ & 1 & 2 & 3 & 4 & 5 & 6 & 7 & 8 & 9 & 10 & 11 & 12 & \begin{tabular}{|l|}
13 \\
\end{tabular} & 14 & 15 \\
\hline \multirow{7}{*}{ 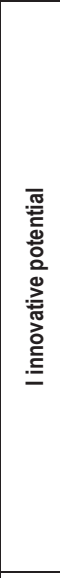 } & $\begin{array}{l}\text { share of population } \\
\text { employed in research and } \\
\text { development, \%o }\end{array}$ & $\mathrm{x}_{11}$ & 4,70 & 4,60 & 4,00 & 3,90 & 15,6 & $|0,125|$ & 37,6 & 36,8 & 32,0 & 31,2 & 124,8 & 0,056 & 2 & 0,964 & 1 \\
\hline & \begin{tabular}{|l|} 
share of innovation - active \\
organizations, $\%$
\end{tabular} & $\mathrm{x}_{12}$ & 8,00 & 11,90 & 13,80 & $|12,00|$ & 15,3 & $4,482 \mid$ & 1,785 & 2,655 & 3,079 & 2,677 & 3,414 & 0,002 & 5 & 0,026 & 4 \\
\hline & $\begin{array}{l}\text { the proportion of acquired } \\
\text { research and development } \\
\text { funds in their total cost,\%o }\end{array}$ & $\mathrm{x}_{13}$ & 4,70 & 9,90 & 5,70 & 3,00 & 38,9 & $|6,467|$ & 0,727 & 1,531 & 0,881 & 0,464 & 6,015 & 0,003 & 4 & 0,046 & 3 \\
\hline & \begin{tabular}{|l} 
the share of domestic \\
expenditure on research and \\
development in the GRP, \%
\end{tabular} & $\mathrm{X}_{14}$ & 5,3 & 6,3 & 6,2 & 7,6 & 22,7 & $|0,672|$ & 7,881 & 9,368 & 9,219 & 11,301 & 33,755 & 0,015 & 3 & 0,261 & 2 \\
\hline & $\begin{array}{l}\text { the share of expenditure on } \\
\text { technological innovation in } \\
\text { the GRP (WFP),\%o }\end{array}$ & $\mathrm{X}_{15}$ & 2,90 & 7,70 & 12,00 & $|10,70|$ & 14,2 & $\begin{array}{c}12,24 \\
2\end{array} \mid$ & 0,237 & 0,629 & 0,980 & 0,874 & 1,160 & 0,001 & 6 & 0,009 & 5 \\
\hline & $\begin{array}{l}\text { the share of innovative } \\
\text { products, services and } \\
\text { works in GRP (WFP),\%o }\end{array}$ & $x_{16}$ & 16,2 & 17,6 & 12,7 & 5,2 & 24,0 & $\begin{array}{c}23,07 \\
7\end{array}$ & 0,702 & 0,763 & 0,550 & 0,225 & 1,040 & 0,0005 & 7 & 0,008 & 6 \\
\hline & $\begin{array}{l}\text { proportion of the } \\
\text { economically active } \\
\text { population, \%o }\end{array}$ & $x_{17}$ & 5,35 & 5,38 & 5,33 & 5,46 & 5,5 & 0,002 & 2183,7 & 2195,9 & 2175,5 & 2228,6 & 2228,6 & 0,998 & 1 & $x$ & $x$ \\
\hline \multirow{2}{*}{ 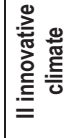 } & regional standard field & $\mathrm{x}_{21}$ & 3,30 & 3,30 & 3,30 & 3,30 & 10,0 & 0,00 & $x$ & $x$ & $x$ & $x$ & $x$ & $x$ & $x$ & $x$ & $x$ \\
\hline & infrastructure provision & $x_{22}$ & 5,60 & 5,60 & 5,60 & 5,60 & 7,0 & $0,00 \mid$ & $X$ & $X$ & $x$ & $x$ & $x$ & $x$ & $x$ & $x$ & $x$ \\
\hline
\end{tabular}

Let us analyze the terms of each block, forming a definition of "innovation susceptibility of the region." The study of innovative climate in the region through the system of quality indicators conducted by the authors in works (Vladimirova,2011). The obtained results allow us to conclude that this category is fairly static for short periods of time (up to 5 years) has no distinct dynamic changes, because it is formed under the influence of factors related to the legal framework and the availability of infrastructure in the region, and is a reflection of the sluggish bureaucratic system. The results of calculations carried out by Unit II in Tables 3 and 4, confirm the absence of variation in the characteristics in the investigated time interval, which excludes significant influence of this group of factors on the dynamics of changes in the complex index of "innovative susceptibility of the region." Consequently, the considered indicators do not have a significant potential in the interval 2005-2009, influence equally on innovation susceptibility of the region as a constant, so the authors considered it possible at this stage of the study to eliminate the impact of the innovation climate in the region on a general indicator.

Factors in group I, defining the innovative potential of the region, have both positive and negative dynamics of the interval 2001-2009 and significantly are different from the same values in the Tomsk region, indicating the unstable development of Krasnoyarsk region, reducing its attractiveness. For a more visual presentation of the achieved level as the unit results calculated in Table 4 by 6-factor system are performed in Figure 2. The standardized reference value on indicators is taken as 100 percent, and the standardized actual values of the terms of unit for each year are translated into a percentage of the standard for more convenient layout of indicators on the chart. 
Figure 2 - The dynamics of the ratio actually achieved and target values of the indexes of the unit "innovative potential of the region"

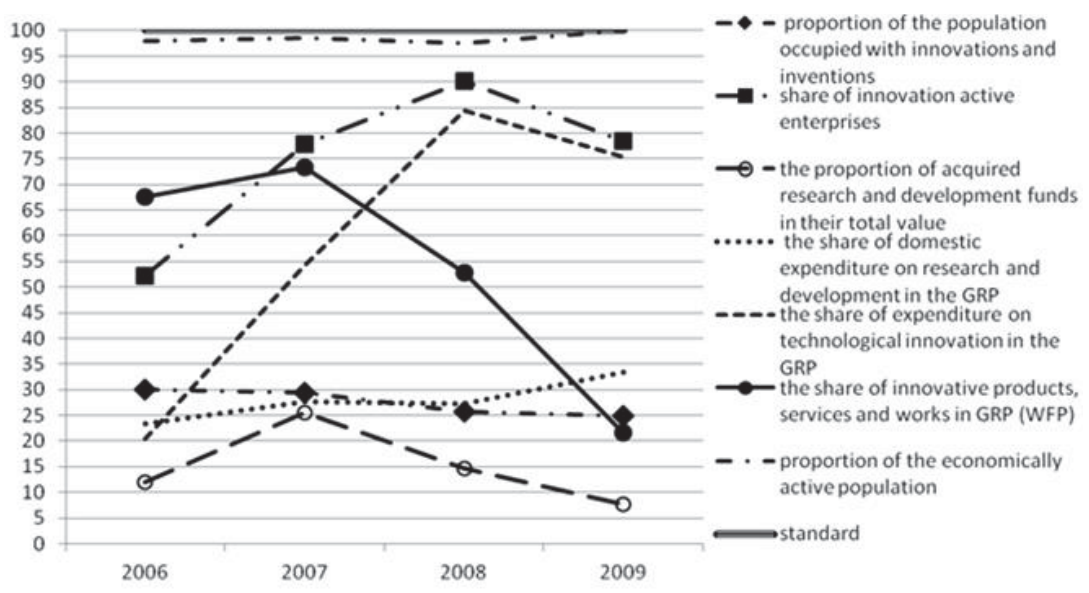

The largest gap between the reference value and the actual achieved level is observed in terms of "a share of the acquired fixed assets of investigations and developments in their total value." In terms of "a share of innovation active organizations" and "a share of the costs of technological innovation in the GRP (WFP)" in the period 2006-2008 there is a sharp jump, which correlates with the policy of regional authorities in terms of attracting of innovative technologies into the region. These two parameters are the most close to the level of the Tomsk region. The remaining terms of the block at the varying dynamics of development by 2009 are in the range of $22 \%$ to $34 \%$ of the target value.

According to the calculations potential functions are generated by two periods on the basis of the 7-and 6-factor system and using the equity method are converted into the following dependencies (Table. 5).

Table 5 - The potential and adjusted functions of the innovative capacity of the Krasnoyarsk Territory

\begin{tabular}{|c|c|c|}
\hline Years periods & The 7-factorial system & The 6-factorial system \\
\hline \multicolumn{3}{|c|}{ Potential functions } \\
\hline 2001-2005 & $\begin{aligned} Y & =0,605 * x_{11}+0,011 * x_{12}+0,012 * x_{13}+ \\
& +0,030 * x_{14}+0,005 * x_{15}+0,004 * x_{16}+0,792 * x_{12}\end{aligned}$ & $\begin{aligned} Y= & 0,998 * x_{11}+0,017 * x_{12}+0,020 * x_{12}+ \\
& +0,049 * x_{14}+0,007 * x_{15}+0,006 * x_{16}\end{aligned}$ \\
\hline 2006-2009 & $\begin{array}{l}Y=0,056 * x_{11}+0,002 * x_{12}+0,003 * x_{13}+ \\
+0,015 * x_{14}+0,001 * x_{15}+0,001 * x_{16}+0,998 * x_{17}\end{array}$ & $\begin{aligned} Y= & 0,964 * x_{11}+0,026 * x_{12}+0,046 * x_{13}+ \\
& +0,261 * x_{14}+0,009 * x_{15}+0,008 * x_{16}\end{aligned}$ \\
\hline \multicolumn{3}{|c|}{ Adjusted functions } \\
\hline 2001-2005 & $\begin{aligned} Y & =0,415 * x_{11}+0,008 * x_{12}+0,008 * x_{13}+ \\
& +0,021 * x_{14}+0,003 * x_{15}+0,003 * x_{16}+0,543 * x_{17}\end{aligned}$ & $\begin{aligned} Y= & 0,91 * x_{11}+0,02 * x_{12}+0,02 * x_{13}+ \\
& +0,04 * x_{14}+0,01 * x_{15}+0,01 * x_{16}\end{aligned}$ \\
\hline 2006-2009 & $\begin{array}{l}Y=0,052 * x_{11}+0,002 * x_{12}+0,003 * x_{13}+ \\
+0,014 * x_{14}+0,001 * x_{15}+0,001 * x_{16}+0,928 * x_{17}\end{array}$ & $\begin{aligned} Y= & 0,73 * x_{11}+0,02 * x_{12}+0,04 * x_{13}+ \\
& +0,20 * x_{14}+0,01 * x_{15}+0,01 * x_{16}\end{aligned}$ \\
\hline
\end{tabular}

The analysis of the results leads to the following conclusions. Firstly, the ranking weight values of the parameters calculated by the seven- and six-terms (with the exception of the indicator "proportion of the economically active population") for two periods, does not change the priority of the factors in the resulting models, forming the system. The greatest influence on the innovative potential of the region has a share of the economically active population. Reaching the target value of this parameter, the second most important was "the share of population employed in research and development" (2nd place in the 7-factor system and 1st place in the 6-factor system). These two parameters are interdependent and this function confirms this. The next most important factor is the "share of domestic expenditure on research and development in the GRP." The cumulative effect of the three main components in a 7 -factor system in the interval 2001-2005 was 97.9\%, in the interval 2005-2009 - 99.4\%. The transition to a 6-factor system did not change the picture - parameters "proportion of the population engaged in research and development" and "the share of domestic expenditure on research and development in the GRP" formed a comprehensive assessment of the unit by 95\% and 93\% at two time intervals, respectively. The share participation of other factors is not significant.

Second, the rank of the weight values of function parameters for two analyzed periods did not change, which suggests that this trend continues today. Therefore, formed additive models allow calculation of an integrated 
assessment of innovation potential of the region for six and seven-factor system and allow the system to forecast the short-term period.

In the next stage of research, it is necessary to assess the status and dynamics of innovation receptivity region in order to identify weaknesses in its development and the development of activities to achieve the desired (target) level. The calculation of the potential function of the unit, conducted according to the 2006-2009 period allows to create a comprehensive assessment, which determines the position of the subject and the leader of the region (Table 6). The comparison of this result for the region with the data allows to determine the standard deviation from the set point of growth, which is referred to as "the growth differential". In a relative form, this parameter is reflected in the index "achieved level." For controlling the block "innovation potential" at the regional management there is a need to determine the required and sufficient level of adhesion of the function to achieve a given parameter, which is reflected by the indicator "the necessary level of differential growth." The methodological justification for the use of the listed parameters and testing calculation algorithm is developed by the authors in their research (Petrova, 2006).

Table 6 - The potential function on the block "Innovation potential of the region"

\begin{tabular}{|l|c|c|c|c|c|}
\hline \multirow{2}{*}{ Indicators } & \multirow{2}{*}{ Calculation methodology } & \multicolumn{5}{|c|}{ Years } \\
\cline { 3 - 6 } & $y_{k}=\sum_{j=1}^{n} \beta_{k j} * z_{k j}$ & 38,38 & 38,07 & 33,38 & 33,12 \\
\hline Potential values of the functions & $y_{k}^{*}=\sum_{j=1}^{n} \beta_{k j} * z_{k j}^{*}$ & \multicolumn{5}{|c|}{129,48} \\
\hline The target value of the potential function & $D_{i k}=y_{k}^{*}-y_{k}$ & 91,09 & 91,41 & 96,10 & 96,36 \\
\hline Growth differential & $C_{k i}=\frac{y_{k}}{y_{k}^{*} * 100}$ & 29,65 & 29,40 & 25,78 & 25,58 \\
\hline Achieved level, \% & $I D_{k i}=\frac{y_{k}^{*}}{y_{k}^{*}} * 100$ & 337,32 & 340,15 & 387,86 & 390,93 \\
\hline The required level of growth differential, \% & & &
\end{tabular}

The results of the ratio of potential values of the functions and the target level are reflected more clearly in Figure 3.

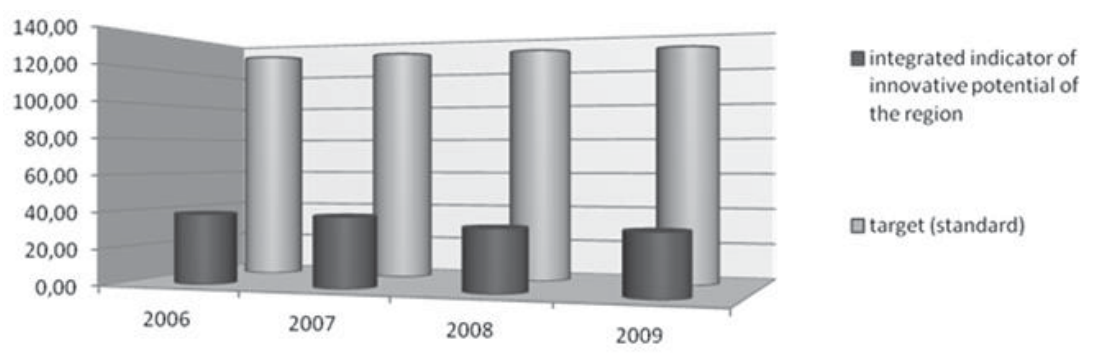

Fig. 3 - The dynamics of the ratio actually achieved and the target value of the complex index of the innovative potential of the region

The received results indicate that the achieved level of innovative potential in the Krasnoyarsk region in 2009 corresponds the target values only $25 \%$. For four years, the gap between the performance in the Krasnoyarsk and Tomsk region increased by more than $4 \%(25,58-29,65)$. To achieve the parameters of the leading region it is necessary to take measures to raise the level of index that form the potential for innovation.

\section{Conclusion}

Thus, the authors consider two sets of terms of the first level, characterizing the innovation climate and innovation potential of the region (Figure 1). The analysis of the dynamics of the innovation climate in the region allowed to conclude the absence of significant shifts in their development and consequently, stagnation of the regional control system. To detect changes in the system of management of innovative climate in the region a more detailed study of the system parameters is required. The algorithm of influence of groups of factors in the absence of dynamics in their development as a constant in the general characteristic of innovative potential of the region is formed by two vectors. Reaching a block 
of reference value by the terms constant acts as a catalyst for the process, even when there is no visible change in the short-term dynamics. In the Krasnoyarsk Territory the values in the block in the interval 2006-2009 in terms of "infrastructural support" and "regional standard field" make up just over $80 \%$ and $30 \%$ of the reference values (Table 4), which significantly slows down the development of innovative technologies. And if the first indicator reflects the result of the development of the region for several decades, the second is a direct reflection of the effectiveness of modern management. Such a scenario for the block development is unacceptable for fulfilling the potential of the subject of federation as an innovative platform, since the development of the economic system in the implementation of innovative development objectives should be sustained.

The investigation of the second block of the first level of "innovation potential of the region" showed a mixed trend changes in its terms, which affected the decrease in integrated assessment, and showed a significant deviation of the achieved level of the target value of the potential function (Table 6).

Thus, the development of a comprehensive evaluation of innovation susceptibility of the region on the basis of the study makes it possible to identify the main trends to improve the management of innovative activity in the subjects of the Russian Federation.

\section{References}

Borodin, V.A. New Industrialization - a long-term industrial policy in the region // Vestnik of Altai science. - 2013. - №3. - p. 34-38. http://vestnik.altkibd.ru/pdf/VAN_2013_3.pdf

Schumpeter, J. The Theory of Economic Development. M.: Economics, 1982 - 277 p.

Lundvall B.-A. (ed). National Systems of Innovation: Towards a Theory of Innovation and Interactive Learning. L.: Pinter Publishers, 1992. uni-klu.ac.at/wiho/downloads/lundvall.ppt

Nelson R. (ed). National Innovation Systems. A Comperative Analysis. Oxford: Oxford University Press, 1993. http://www.amazon.com/ National-Innovation-Systems-Comparative-Analysis/dp/0195076176

Freeman C. The National System of Innovation in Historical Perspective // Cambridge Journal of Economics. 1995. Vol. 19, № 1

Hamidov, G.S. et al. Fundamentals of Innovation and innovation activities. SPb.: Polytechnic, 2000. 323 p.

Mityakov, S.N., Mityakova, O.I., Fedoseyeva, T.A. Assessment of the level of innovational and industrial development of economic systems // Proceedings of the NSTU. Prospects for Development: history, PR, management, education in higher education, sociology, economics, philosophy. T. 52, Nizhniy Novgorod, 2005, pp. 46-49.

Tatarkin, Al, Sukhovey, AF Formation of innovative areas in the context of the problems of technological modernization of economy II Innovations. 2005. № 7. S. 26-30.

Head, I.M. Innovative climate region: problems of formation and evaluation. Ekaterinburg: Institute of Economics Ural. Dep-of Sciences, 2007. $178 \mathrm{p}$.

Fatkhutdinov, R. Simplification of the Shrew. How to improve the competitiveness of Russian// Poisk. 2004. № 4. p.4.

Muchie M., Baskaran A. Creating a system of innovation in Africa. Country Studies. Africa Institute of South Africa, $2013-236$ p. http://www.globelics.org/wp-content/uploads/2013/01/Book-Notification-Creating-Systems-of-Innovation-in-Africa.pdf

Lundvall B.-A., Intarakumnerd P., Vang J. Asia's Innovation Systems in Transition (New Horizons in the Economics of Innovation.) Edward Elgar Publishing Ltd, USA, 2006 - 322p. http://bookfi.org/book/1045442

Lundvall B.-A., Joseph K.J., Chaminade C., Vang J. (eds.) Handbook on Innovation Systems and Developing Countries: Building Domestic Capabilities in a Global Setting - Edward Elgar Publishing Ltd, USA, 2010. - 395 p. http://bookfi.org/book/1140645

Vladimirova, O.N. Innovative region susceptibility, conditions of formation and management: Monograph / O. N. Vladimirova: Krasnoyarsk State Trade and Economics Institute, Krasnoyarsk, 2011.

Innovation Measurement: Tracking the State of Innovation in the American Economy. Department of Commerce USA // URL: www. Innovationmetrigs.gov

European Innovation Scoreboard 2010: Comparative Analysis of Innovation Performance. - Brussels, 2011. - 72 p.

The State Program of innovative development of the Republic of Belarus in 2011-2015. [Electronic resource] // State committee of Science and Technology of the Republic of Belarus. - Mode of access: <http://gknt.org.by/gpir/ rojectGPIR2011-2015 />. - Access Date: 15.04 .2014$.

Petrova, A.T. Theory, methodology of statistical research and practice of the life quality control of the population of the region / Petrova A.T. - M.: Finance and Credit. - 2006 - 280 p. http://www.fin-izdat.ru/book/_index.php?ELEMENT_ID=7019

Shalanov N.V. Mathematical economics / N.V. Shalanov - Novosibirsk: IGN 2005. - 259 p.

Hunt J. Markov processes and potentials lane. trans. from eng., M., 1962 - 283p. http://www.twirpx.com/file/561468/

Meyer P. - A., Probability and potentials, trans. from eng., M., $1973-330 \mathrm{p}$. 